Acta Protozool. (2018) 57: 153-167

www.ejournals.eu/Acta-Protozoologica doi:10.4467/16890027AP.18.013.10089

\title{
PROTOZOOLOGICA
}

\section{Morphology of Three Aloricate Choreotrich ciliates, Including Description of a New Species Parastrombidinopsis costalis sp. n. (Ciliophora, Choreotrichia), and phylogeny of the genus Parastrombidinopsis}

\author{
Wen SONG ${ }^{a} \uparrow$, Jiamei LI ${ }^{a} \uparrow$, Yaoyao HUANG ${ }^{b}$, Xiaozhong HUa, Weiwei LIU', Khaled A. S. AL- \\ RASHEID ${ }^{\mathrm{d}}$ and Miao MIAO \\ a Laboratory of Protozoology, Institute of Evolution and Marine Biodiversity, Ocean University of China, Qingdao, China \\ ${ }^{b}$ Laboratory of Protozoology, Guangzhou Key Laboratory of Subtropical Biodiversity and Biomonitoring, School of Life Science, \\ South China Normal University, Guangzhou, China \\ ${ }^{\mathrm{c}}$ Key Laboratory of Tropical Marine Bio-resources and Ecology, South China Sea Institute of Oceanology, Chinese Academy of \\ Science, Guangzhou, China \\ d Zoology Department, College of Science, King Saud University, Riyadh, Saudi Arabia \\ e Savaid Medical School, University of Chinese Academy of Sciences, Beijing, China \\ $\uparrow$ These two authors contribute equally
}

\begin{abstract}
As a follow-up part of our studies of the tropical ciliate fauna carried out in the last decade, we investigated the morphology and phylogeny of three choreotrich ciliates, viz., Parastrombidinopsis costalis sp. n., P. pelagica (Fauré-Fremiet, 1924) comb. n. and P. minima Tsai et al., 2008. The new species is characterized by its unique asymmetrical cell shape, 19-21 collar membranelles, one buccal membrane, and eight unevenly distributed somatic kineties. An improved diagnosis of $P$. pelagica (Fauré-Fremiet, 1924) comb. n. is given based on the original and current studies, the species is characterized by a large cell size, an elongate obconical cell shape, 31-36 collar membranelles and 13-15 somatic kineties. The species $P$. minima is redescribed based on a new population with some new features supplemented. SSU rRNA genes of both the new species and P. minima were sequenced and a phylogenetic review of related taxa obtained has been performed in order to reveal their systematic relationships. The monophyly of the genus Parastrombidinopsis is highly supported in our phylogenetic analyses.
\end{abstract}

Keywords: choreotrich ciliates; ciliature; new combination; Strombidinopsidae; SSU rRNA gene; taxonomy

Address for correspondence: Miao Miao, Savaid Medical School, University of Chinese Academy of Sciences, Beijing 100049, China; Telephone number: +86 106967 2489; FAX: +86 106967 2489; E-mail: miaomiao@ucas.ac.cn Weiwei Liu, Key Laboratory of Tropical Marine Bio-resources and Ecology, South China Sea Institute of Oceanology, Chinese Academy of Science, Guangzhou 510301, China; Telephone number: +86 208910 7442; FAX: +86 208910 7442; E-mail: wwliu@scsio.ac.cn 


\section{INTRODUCTION}

Aloricate choreotrich ciliates, together with tintinnid and oligotrich ciliates, are often dominant components of the marine microzooplankton, and play important roles in the microbial food web (Liu et al. 2017, Santoferrara and McManus 2017, Santoferrara et al. 2017, Smith et al. 2018, Song et al. 2018, Wang et al. 2018, Zhang et al. 2017). Comprising four families, aloricate choreotrichs have been well investigated in terms of morphology and phylogeny (Lynn and Montagnes 1988; Montagnes and Taylor 1994; Petz et al. 1995; Song and Packroff 1997; Song and Bradbury 1998; Song et al. 1999, 2000, 2009; Agatha 2003; Agatha et al. 2005; Song 2005; Agatha and Strüder-Kypke 2007, 2012; Gao et al. 2009, 2016a, b, 2017; Xu et al. 2009, 2017; Kim et al. 2010; Zhang et al. 2010; Li et al. 2013; Huang et al. 2014, 2016; Chen et al. 2016; Yan et al. 2016; Zhao et al. 2017), and some new taxa have been reported in recent years (Kim et al. 2005, Xu et al. 2006, 2008, Alekperov et al. 2007, Liu et al. 2012, 2016, Chen et al. 2017).

Members of the choreotrich family Strombidinopsidae Small \& Lynn, 1985 are mostly small to mediumsize, spheroid to conoid ciliates that are characterized by the possession of a circle of collar membranelles and longitudinal kineties equally distributed around the cell (Agatha 2003, Lynn 2008, Liu et al. 2012). There are three genera in the family, namely, Strombidinopsis Kent, 1881 (type), Parastrombidinopsis Kim et al., 2005, and Parastrombidium Fauré-Fremiet, 1924. Parastrombidinopsis differs from the others in having an open zone of collar membranelles which are not distally elongated. Up to now, Parastrombidinopsis includes only two species (Kim et al. 2005, Tsai et al. 2008).

During a faunistic study of choreotrich ciliates in China, three Parastrombidinopsis species, including one new form, were isolated; here, their morphological information and SSU rRNA gene sequences are reported.

\section{MATERIALS AND METHODS}

\section{Collection, isolation and morphological studies}

Information on sampling sites and ecological features are displayed in Table 1.

Samples of Parastrombidinopsis costalis sp. n. (Zhuhai) and $P$. minima were collected directly from surface coastal waters $(0-$
$0.5 \mathrm{~m}$ ) using $100 \mathrm{ml}$ bottles (Figs 1C, D); samples of P. costalis sp. n. (Sanya) were collected directly from mangrove wetland using $100 \mathrm{ml}$ bottles (Fig. 1E); samples of Parastrombidinopsis pelagica (Fauré-Fremiet, 1924) comb. n. were collected using a $20 \mu \mathrm{m}$ mesh plankton net from surface coastal water $(0-0.5 \mathrm{~m})$ (Fig. 1B). The samples were then transferred to Petri dishes and the specimens were immediately isolated for further investigation. The morphology of living cells was studied using bright-field and differential interference contrast microscopy. Live observations were performed at $\sim 20{ }^{\circ} \mathrm{C}$. Protargol staining (Wilbert 1975) was used to reveal the infraciliature, and protargol was made according to Pan et al. (2013). Drawings of live cells were based on photomicrographs; those of silver-stained cells were made with the help of a camera lucida. Counts and measurements were performed at a magnification of $\times 1000$. Terminology is according to Agatha and Riedel-Lorjé (2006) and taxonomic system is mainly according to Gao et al. (2016a).

\section{Extraction, amplification and sequencing of DNA}

Genomic DNA was extracted using a DNeasy Blood \& Tissue kit (Qiagen, CA) following the manufacturer's instruction ( $1-5$ cells per $45 \mu \mathrm{l}$ of ATL solution). Unfortunately, the DNA extraction of Sanya population of $P$. costalis sp. n. and $P$. pelagica failed, and thus only $P$. minima and Zhuhai population of $P$. costalis $\mathrm{sp} . \mathrm{n}$. are available for further study. The PCR conditions and the primers used to amplify the SSU rRNA gene followed that of previous studies (Medlin et al. 1988). PCR products were sequenced without cloning. Sequencing was conducted bidirectionally on an ABI-PRISM 3730 sequencer (Shanghai Sunny Biotechnology Co. Ltd., Shanghai, China). The sequences were assembled by ContigExpress.

\section{Phylogenetic analyses}

In addition to the two species of Parastrombidinopsis in this study, the SSU rRNA gene sequences of 42 species of Choreotrichia and Oligotrichia obtained from GenBank were used to construct the phylogenetic trees; five species (representing five genera) of Halteriida and Hypotrichia were used as the outgroup taxa.

All 49 sequences were aligned using Bioedit (Hall 1999) with default parameters, and the ends of alignments were trimmed yielding a matrix of 1650 characters. Maximum likelihood (ML) analyses were conducted using RaxML-HPC2 on XSEDE (8.2.10) (Stamatakis 2006, Stamatakis et al. 2008) with the default model provided on the online server CIPRES Science Gateway (Miller et al. 2010). The reliability of internal branches was assessed using a nonparametric bootstrap method with $10^{3}$ replicates.

Bayesian inference (BI) analysis was performed using MrBayes 3.2.6 on XSEDE v 3.2.6 (Ronquist and Huelsenbeck 2003) provided on the CIPRES Science Gateway with the model GTR $+\mathrm{I}+\mathrm{G}$ selected by the Akaike Information Criterion (AIC) in MrModeltest v2 (Nylander 2004). Markov chain Monte Carlo analyses were run for $4 \times 10^{6}$ generations with two parallel runs, each with four simultaneous chains, sampling every 100 generations. The first 10000 trees were discarded as burn-in. The remaining trees were used to calculate the posterior probabilities (PP) applying the majority rule consensus. 
Table 1. Ecological features of the sampling sites for the three Parastrombidinopsis species. T, water temperature; S, salinity.

\begin{tabular}{|c|c|c|c|c|c|}
\hline Species & $\mathrm{T}^{\circ} \mathrm{C}$ & $\mathrm{S} \%$ & $\mathrm{pH}$ & Sampling site & Date \\
\hline $\begin{array}{l}\text { P. costalis sp. n. } \\
\text { Zhuhai pop. }\end{array}$ & 29.2 & 2.5 & 8.0 & Zhujiang estuary in Zhuhai $\left(22^{\circ} 29^{\prime} \mathrm{N}, 113^{\circ} 58^{\prime} \mathrm{E}\right)$, China & June, 2014 \\
\hline $\begin{array}{l}\text { P. costalis sp. } \mathrm{n} . \\
\text { Sanya pop. }\end{array}$ & 27.0 & 30.0 & - & coastal waters off Sanya $\left(18^{\circ} 14^{\prime} \mathrm{N}, 109^{\circ} 31^{\prime} \mathrm{E}\right)$, China & April, 2018 \\
\hline $\begin{array}{l}\text { P. pelagica } \\
\text { (Fauré-Fremiet, 1924) } \\
\text { comb. n. }\end{array}$ & 25.2 & 25.0 & 7.8 & coastal waters off Zhanjiang $\left(21^{\circ} 14^{\prime} \mathrm{N}, 110^{\circ} 35^{\prime} \mathrm{E}\right)$, China & November, 2013 \\
\hline P. minima Tsai et al., 2008 & 29.9 & 18.2 & 8.8 & brackish waters in Haikou $\left(20^{\circ} 06^{\prime} \mathrm{N}, 110^{\circ} 33^{\prime} \mathrm{E}\right)$, China & April, 2014 \\
\hline
\end{tabular}
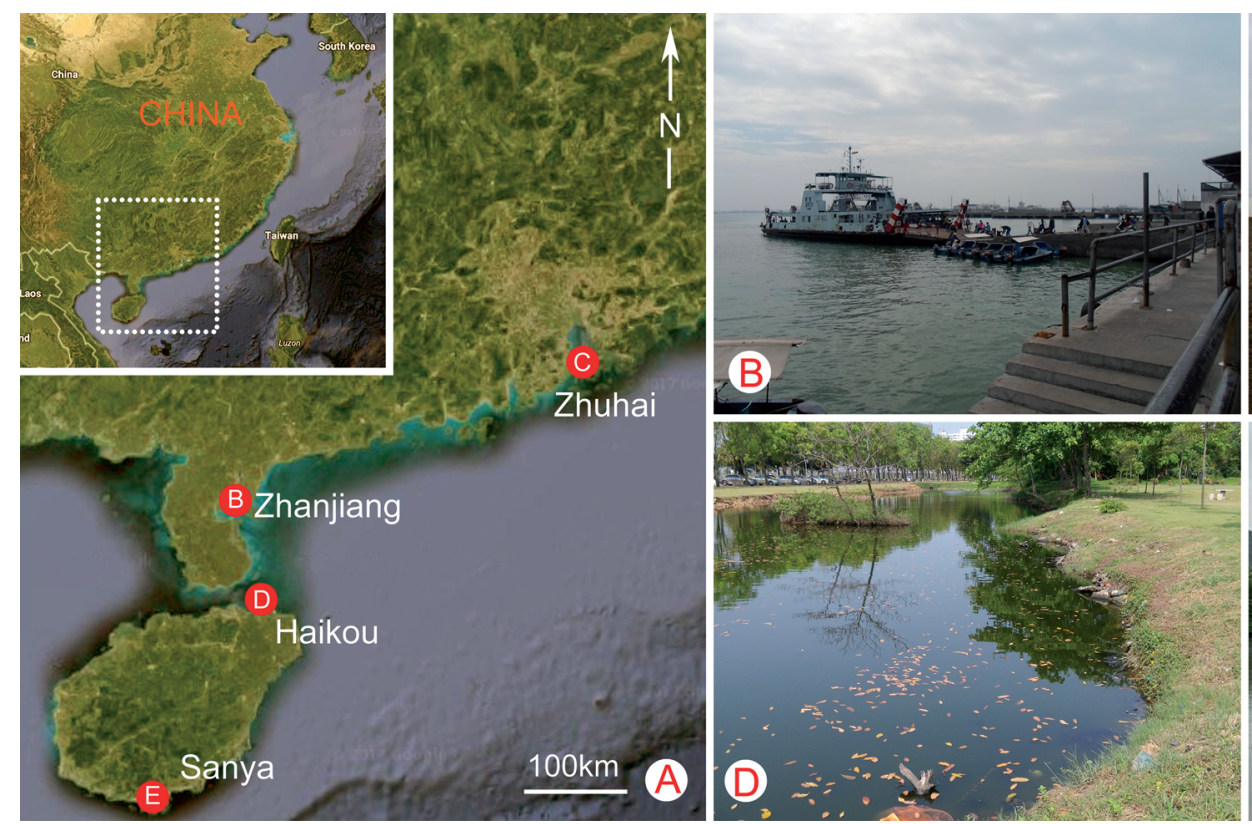

Fig. 1. Satellite photograph of South-East China (A) and pictures of sampling sites (B-E). (A) The position of Zhanjiang, Zhuhai, Haikou and Sanya. (B) Coastal waters off Zhanjiang. (C) Coastal waters off Zhuhai. (D) Brackish waters in Haikou. (E) Mangrove wetland in Sanya.

\section{RESULTS}

Subclass Choreotrichia Small \& Lynn, 1985 Order Choreotrichida Small \& Lynn, 1985

Family Strombidinopsidae Small \& Lynn, 1985

Genus Parastrombidinopsis Kim et al., 2005

\section{Parastrombidinopsis costalis sp. n. (Fig. 2, 3, Table 2)}

LSID urn:1sid:zoobankorg:act:AFC712DF-986145DA-9387-57F93BCCC73E

The diagnosis and description are based on two populations, one collected from Zhuhai and one collected from Sanya. The Zhuhai population is the type population for this new species.

Diagnosis: Cell size 30-70 $\times 15-40 \mu \mathrm{m}$ in vivo, $25-73 \times 13-42 \mu \mathrm{m}$ after protargol staining. Body asymmetrically cylindrical with an obvious longitudinal ridge on dorsal side. One buccal membranelle and 16-21 collar membranelles, with proximal end located below the distal end. Six to eight somatic kineties with three to five kineties extending ventrally and three kineties extending dorsally, each composed of 8-33 dikinetids. Two ellipsoidal macronuclear nodules. Brackish and marine habitat. 


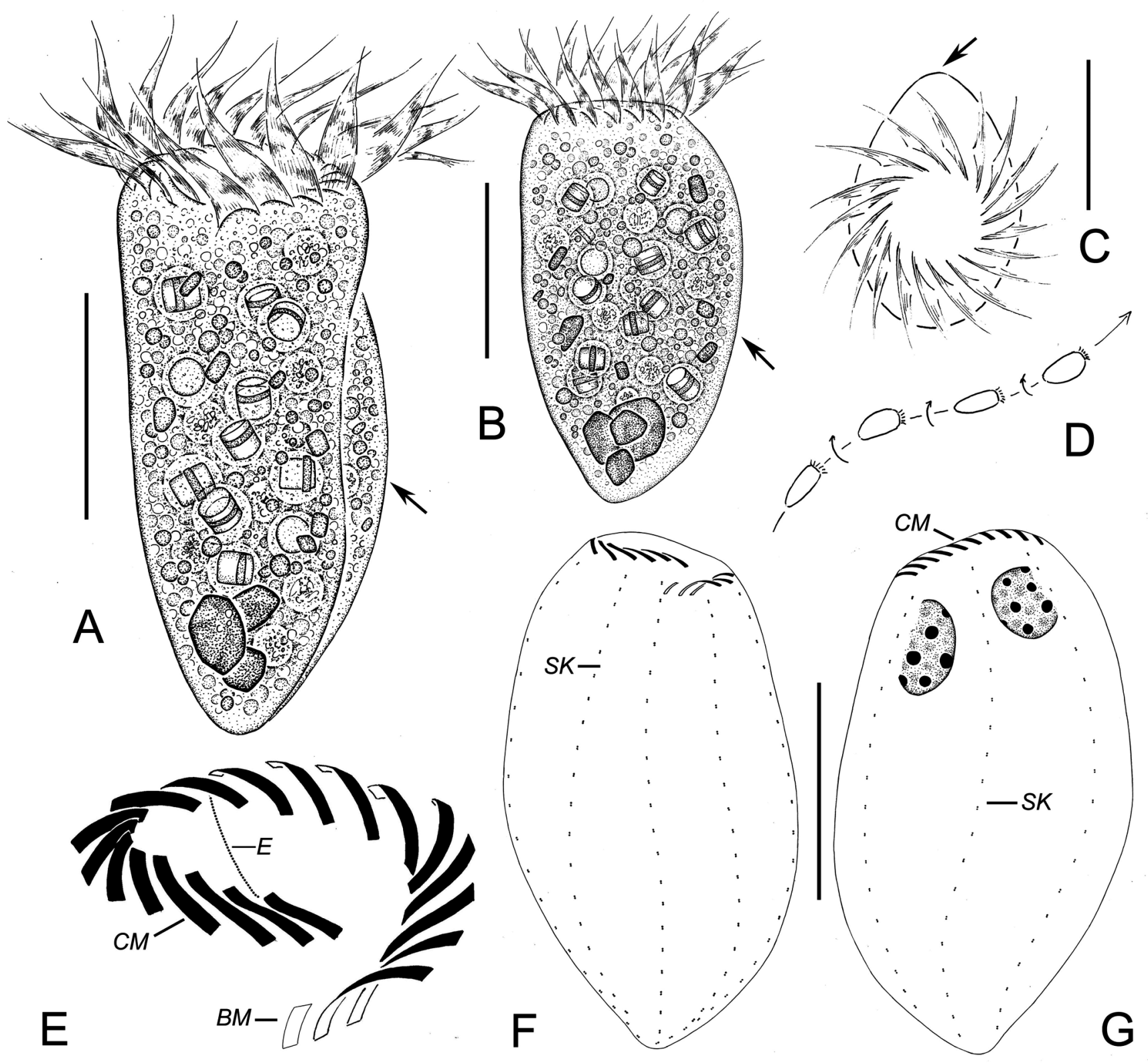

Fig. 2. Parastrombidinopsis costalis sp. $\mathrm{n}$. of Zhuhai population from life (A-D) and after protargol staining (E-G). (A, B) Ventral and left lateral views of representative individuals; arrows mark the dorsal ridges. (C) Apical view, showing collar membranelles and body shape; arrow marks the dorsal ridge. (D) Locomotion. (E) Oral ciliature. (F, G) Ventral and dorsal views of the same specimen. BM, buccal membranelle; CM, collar membranelles; E, endoral membrane; SK, somatic kinety. Scale bars: $25 \mu \mathrm{m}$.

Type locality: Zhujiang estuary in Zhuhai $\left(22^{\circ} 29^{\prime} \mathrm{N}\right.$, $\left.113^{\circ} 58^{\prime} \mathrm{E}\right)$, China. Salinity about $2.5 \%$.

Type material: A protargol slide containing the holotype specimen marked with an ink circle and another two protargol slides containing the paratype specimens are deposited in Laboratory of Protozoology,
OUC, China (registration number: SW2014060201-1, SW2014060201-2).

Etymology: The Latin word 'costalis' used as species name refers to the longitudinal ridge of cell.

Gene sequence data: The small subunit rRNA gene sequence of Parastrombidinopsis costalis sp. n. col- 

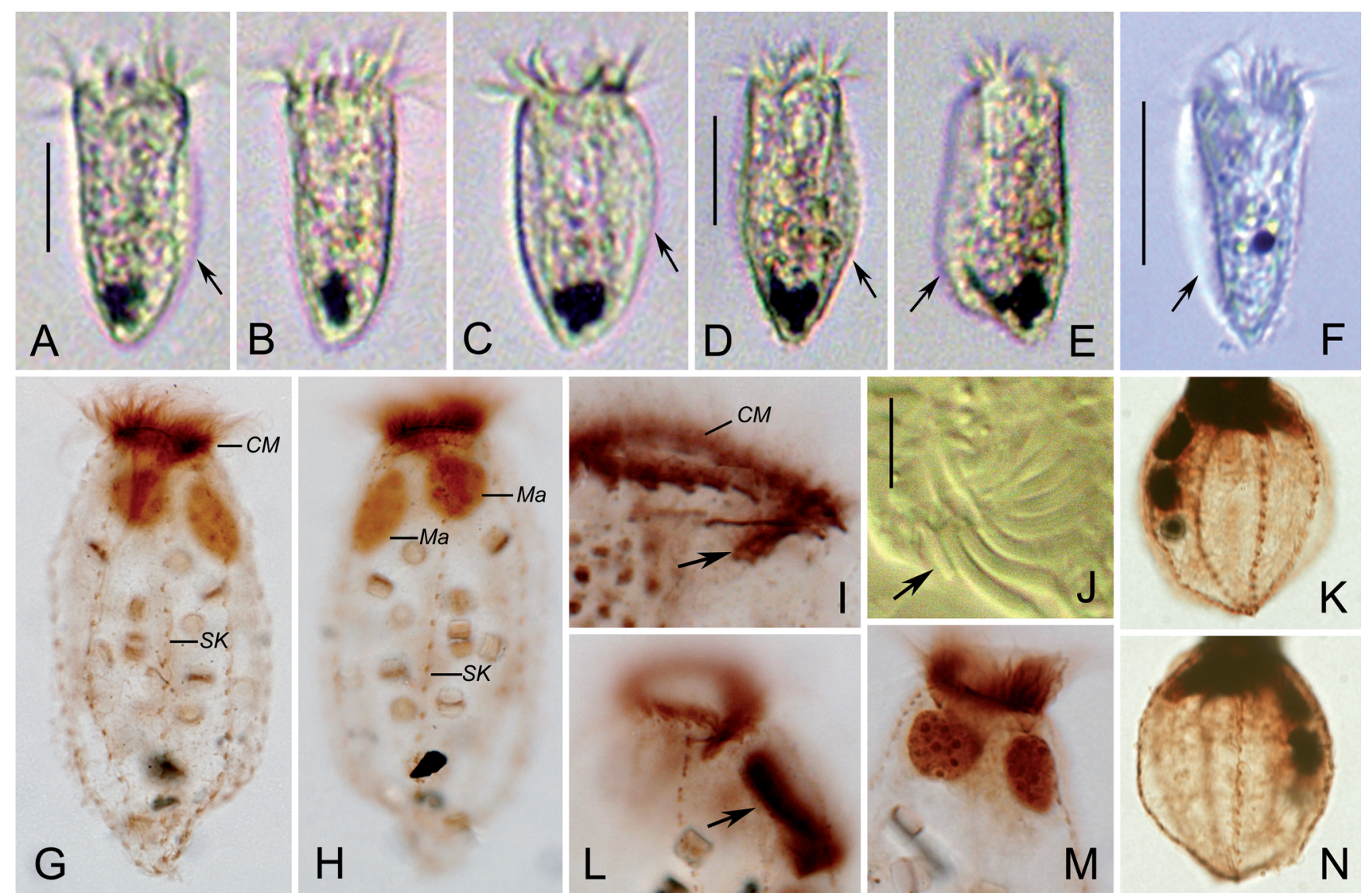

Fig. 3. Photomicrographs of Parastrombidinopsis costalis sp. n. from life (A-F, J) and after protargol staining (G-I, K-N), (A-E, G-J, $\mathrm{L}, \mathrm{M})$ from Zhuhai population, and (F, K, N) from Sanya population. (A-C) Ventral-left, ventral, left-lateral views of one individual, arrows mark the dorsal ridge. (D, E) Ventral-left, ventral-right views of one individual; arrows mark the dorsal ridge. (F) Ventral-right view of one individual, arrow marks the dorsal ridge. $(\mathrm{G}, \mathrm{H})$ Ventral and dorsal views of one specimen, showing the somatic ciliature. (I) Ventral view of oral ciliature; arrow marks buccal membranelle. (J) Bases of oral membranelles; arrow marks buccal membranelle. (L) An early divider; arrow marks the oral primordium. (M) Two macronuclei. (K, N) Ventral and dorsal views of one specimen, showing the somatic ciliature. CM, collar membranelles; Ma, macronucleus; SK, somatic kinety. Scale bars: $25 \mu \mathrm{m}$ (A, D); $20 \mu \mathrm{m}$ (F); $3 \mu \mathrm{m}$ (J).

lected from Zhuhai was deposited in GenBank with accession number MH469225.

Description: Cell size $60-70 \times 25-40 \mu \mathrm{m}$ in vivo, 50-73 $\times 23-42 \mu \mathrm{m}$ after protargol staining in Zhuhai population, cell size 30-40 × 15-20 $\mu \mathrm{m}$ in vivo, 25-45 $\times$ 13-26 $\mu \mathrm{m}$ after protargol staining in Sanya population. Body elongated cylindrical with anterior end transversely truncated and posterior end bluntly pointed; length: width ratio about 2:1 (Figs 2A, 3A-F). An obvious ridge longitudinally extending in the middle of dorsal side in all individuals, making the outline of the cell asymmetrical under lateral and apical views (Figs 2B, C, 3C). The ridge not recognised after protargol staining.

Cytoplasm colourless, with some lipid droplets about $2 \mu \mathrm{m}$ across and food vacuoles $\sim 5 \mu \mathrm{m}$ across contain- ing remnants of ingested bacteria and diatoms; in Zhuhai population, several mineral grains usually found in posterior cell portion, rarely in the middle of cell, dark in vivo (Figs 2A, B, 3A-E). Cell surface smooth, without mineral envelope. Extrusomes and contractile vacuole not observed. Two macronuclear nodules located in the anterior one-fourth to half of cell, 9-15 $\times 5-11 \mu \mathrm{m}$ in size after protargol staining in Zhuhai population, 4-11 $\times 3-8$ $\mu \mathrm{m}$ in size after protargol staining in Sanya population, ellipsoidal, with several nucleoli $2-3 \mu \mathrm{m}$ across (Figs $2 \mathrm{G}, 3 \mathrm{M})$. Micronucleus not recognisable in either live or fixed specimens. Locomotion by swimming forward while rotating about the main cell axis (Fig. 2D).

Oral apparatus in vivo about 25-30 $\mu \mathrm{m}$ across and 13-20 $\mu \mathrm{m}$ across after protargol impregnation in Zhuhai 
Table 2. Morphometric data on Parastrombidinopsis costalis sp. n. of Zhuhai population (first row), P. costalis sp. n. of Sanya population (second row), P. pelagica (Fauré-Fremiet, 1924) comb. n. (third row) and P. minima (fourth row).

\begin{tabular}{|c|c|c|c|c|c|c|c|}
\hline Character & Min & Max & Mean & $\mathrm{SD}$ & SE & $\mathrm{CV}$ & $\mathrm{n}$ \\
\hline \multirow[t]{4}{*}{ Body length } & 50 & 73 & 60.9 & 7.23 & 1.66 & 11.9 & 19 \\
\hline & 25 & 45 & 34.8 & 5.25 & 1.36 & 15.1 & 15 \\
\hline & 95 & 135 & 116.4 & 13.93 & 5.26 & 12.0 & 7 \\
\hline & 67 & 83 & 77.4 & 4.57 & 1.02 & 5.9 & 20 \\
\hline \multirow[t]{4}{*}{ Body width } & 23 & 42 & 32.9 & 4.86 & 1.15 & 14.8 & 18 \\
\hline & 13 & 26 & 19.6 & 3.44 & 0.89 & 17.5 & 15 \\
\hline & 40 & 66 & 54.3 & 9.55 & 3.61 & 17.6 & 7 \\
\hline & 55 & 75 & 65.4 & 5.36 & 1.23 & 8.2 & 19 \\
\hline \multirow{4}{*}{$\begin{array}{l}\text { Anterior cell end to buccal vertex, } \\
\text { distance }\end{array}$} & 5 & 8 & 5.9 & 1.09 & 0.27 & 18.5 & 16 \\
\hline & 4 & 7 & 5.2 & 0.83 & 0.19 & 16.0 & 20 \\
\hline & 13 & 15 & 14.0 & 0.71 & 0.32 & 5.1 & 5 \\
\hline & 7 & 15 & 10.2 & 2.32 & 0.53 & 22.8 & 19 \\
\hline \multirow[t]{4}{*}{ Oral diameter } & 13 & 20 & 15.4 & 1.57 & 0.36 & 10.2 & 19 \\
\hline & 8 & 19 & 11.9 & 2.51 & 0.58 & 21.1 & 19 \\
\hline & 30 & 38 & 34.3 & 2.55 & 0.85 & 7.4 & 9 \\
\hline & 24 & 31 & 28.3 & 1.83 & 0.39 & 6.5 & 22 \\
\hline \multirow[t]{4}{*}{ Number of collar membranelles } & 19 & 21 & 19.8 & 0.84 & 0.37 & 4.2 & 5 \\
\hline & 16 & 19 & 17.7 & 1.53 & 0.88 & 8.6 & 3 \\
\hline & 31 & 36 & 33.2 & 1.94 & 0.79 & 5.9 & 6 \\
\hline & 16 & 18 & 16.6 & 0.70 & 0.22 & 4.2 & 10 \\
\hline \multirow[t]{4}{*}{ Number of buccal membranelles } & 1 & 1 & 1.0 & 0.00 & 0.00 & 0.0 & 2 \\
\hline & 1 & 1 & 1.0 & 0.00 & 0.00 & 0.0 & 2 \\
\hline & - & - & - & - & - & - & - \\
\hline & - & - & - & - & - & - & - \\
\hline \multirow[t]{4}{*}{ Number of somatic kineties } & 8 & 8 & 8.0 & 0.00 & 0.00 & 0.0 & 19 \\
\hline & 6 & 8 & 7.1 & 0.44 & 0.10 & 6.2 & 21 \\
\hline & 13 & 15 & 14.3 & 0.76 & 0.29 & 5.3 & 7 \\
\hline & 14 & 15 & 14.4 & 0.49 & 0.12 & 3.4 & 17 \\
\hline Number of dikinetids in per & 17 & 33 & 21.5 & 3.35 & 0.60 & 15.6 & 31 \\
\hline \multirow[t]{3}{*}{ somatic kinety } & 8 & 22 & 15.2 & 3.56 & 0.84 & 23.4 & 18 \\
\hline & 52 & 79 & 61.6 & 7.54 & 2.27 & 12.2 & 11 \\
\hline & 25 & 39 & 31.3 & 5.31 & 2.01 & 17.0 & 7 \\
\hline \multirow[t]{4}{*}{ Number of macronuclei } & 2 & 2 & 2.0 & 0.00 & 0.00 & 0.0 & 19 \\
\hline & 2 & 2 & 2.0 & 0.00 & 0.00 & 0.0 & 18 \\
\hline & 2 & 2 & 2.0 & 0.00 & 0.00 & 0.0 & 11 \\
\hline & 2 & 2 & 2.0 & 0.00 & 0.00 & 0.0 & 22 \\
\hline \multirow[t]{4}{*}{ Macronucleus length } & 9 & 15 & 11.6 & 1.70 & 0.68 & 14.6 & 17 \\
\hline & 4 & 11 & 7.9 & 1.81 & 0.43 & 23.0 & 18 \\
\hline & 10 & 17 & 14.3 & 2.43 & 0.92 & 17.0 & 7 \\
\hline & 14 & 21 & 16.9 & 2.34 & 0.62 & 13.8 & 14 \\
\hline \multirow[t]{4}{*}{ Macronucleus width } & 5 & 11 & 8.2 & 1.70 & 0.44 & 16.5 & 17 \\
\hline & 3 & 8 & 4.4 & 1.38 & 0.33 & 31.4 & 18 \\
\hline & 8 & 12 & 10.1 & 1.57 & 0.59 & 15.5 & 7 \\
\hline & 12 & 14 & 13.2 & 0.70 & 0.19 & 5.3 & 14 \\
\hline \multirow[t]{4}{*}{ Number of micronuclei } & - & - & - & - & - & - & - \\
\hline & - & - & - & - & - & - & - \\
\hline & 3 & 3 & 3.0 & 0.00 & 0.00 & 0.0 & 2 \\
\hline & - & - & - & - & - & - & - \\
\hline
\end{tabular}

All data are based on randomly selected protargol-stained specimens (Wilbert, 1975). Measurements in $\mu \mathrm{m}$. CV, coefficient of variation in \%; Max, maximum; Mean, arithmetic mean; Min, minimum; n, number of specimens investigated; SD, standard deviation; SE, standard error of arithmetic mean; '-', the character not observed or detected. 
population, for Sanya population, oral apparatus in vivo about $15-20 \mu \mathrm{m}$ across and $8-19 \mu \mathrm{m}$ across after protargol impregnation; oral cavity extending posteriad to about one-tenth of cell length. Adoral zone of membranelles (AZM) composed of 19-21 collar and one buccal membranelles in Zhuhai population, 16-19 collar and one buccal membranelles in Sanya population, both with a conspicuous gap at the ventral side. The AZM slightly spiralled with proximal end located below the distal end. The cilia of the collar membranelles about $15 \mu \mathrm{m}$ long in Zhuhai population, about $10 \mu \mathrm{m}$ long in Sanya population, while the bases of the collar membranelles extend obliquely across the peristomial rim, each composed of three rows of basal bodies; bases about $2 \mu \mathrm{m}$ long, except for two to three elongate bases at the proximal end of the AZM, about $3 \mu \mathrm{m}$ long, extending into the oral cavity. One buccal membranelle located parallel to the most proximal collar membranelle on the oral cavity, with a base about $1 \mu \mathrm{m}$ long (Figs 2E, 3I, J). Endoral membrane inconspicuous, composed of a single row of basal bodies, lying on the inner wall of the buccal cavity (Fig. 2E).

Somatic ciliature arranged in six to eight kineties which generally commence below the membranellar zone and extend longitudinally to the posterior end of cell, without forming a subterminal or subcaudal suture. In stained specimens of Zhuhai population, five somatic kineties arranged on ventral side with distance between adjacent kineties about $8 \mu \mathrm{m}$, three somatic kineties arranged on dorsal side, with distance between adjacent kineties about $15 \mu \mathrm{m}$ (Figs 2F, G, 3G, H). Each somatic kinety consisting of 17-33 dikinetids; in each dikinetid, both basal bodies bear a $3 \mu \mathrm{m}$ long cilium. In stained specimens of Sanya population, three to five somatic kineties arranged on ventral side with distance between adjacent kineties about $7 \mu \mathrm{m}$, three somatic kineties arranged on dorsal side, with distance between adjacent kineties about $10 \mu \mathrm{m}$ (Figs 3K, N). Each somatic kinety consisting of 8-22 dikinetids; in each dikinetid, both basal bodies bear a $2 \mu \mathrm{m}$ long cilium. One early divider was observed in Zhuhai population, its oral primordium located anteriorly at the body left (Fig. 3L).

Parastrombidinopsis pelagica (Fauré-Fremiet, 1924) comb. n. (Figs 4, 5, Table 2)

Synonyms: Strobilidium pelagicum Fauré-Fremiet, 1924

Strombidinopsis pelagicum (Fauré-Fremiet, 1924) Jankowski, 2007
This species was simply described by Fauré-Fremiet (1924), here we present an improved diagnosis based on the original description and the present population.

Improved diagnosis: Cell size 100-170 × 40-60 $\mu \mathrm{m}$ in vivo, 95-135 $\times 40-66 \mu \mathrm{m}$ after protargol staining. Body broadly elongated obconical with posterior portion pointed. About 31-36 collar membranelles with proximal end located below the distal end, no elongated membranelles and buccal membranelle. About 13-15 somatic kineties equally spaced around the body, with 52-79 dikinetids each. Three globular micronuclei, located between two ellipsoidal macronuclear nodules. Marine habitat.

Locality: Coastal waters off Zhanjiang $\left(21^{\circ} 14^{\prime} \mathrm{N}\right.$, $110^{\circ} 35^{\prime} \mathrm{E}$ ), China. Salinity about $25.0 \%$.

Voucher slide: A protargol slide containing voucher specimens is deposited in the Laboratory of Protozoology, OUC, China (registration number: SW2013110202).

Description: Cell size 100-130 × 40-60 $\mu \mathrm{m}$ in vivo, 95-135 × 40-66 $\mu \mathrm{m}$ after protargol staining. Although body shapes vary from slimly to broadly elongated obconical, in essence, anterior two-thirds of cell cylindrical and posterior one-third of cell pointed; length: width ratio about $2.5: 1$ in vivo. Anterior end of body transversely truncated (Figs 4A, B, D, 5A-D).

Cytoplasm colourless, with some lipid droplets about $2 \mu \mathrm{m}$ across and food vacuoles $\sim 8 \mu \mathrm{m}$ across containing some yellow algae (Figs 5C, L). Cell surface smooth, without mineral envelope. Extrusomes and contractile vacuole not observed. Two macronuclear nodules arranged obliquely up and down and located in the anterior half of cell, $10-17 \times 8-12 \mu \mathrm{m}$ in size after protargol staining, ellipsoidal, with several nucleoli $\sim 2-3 \mu \mathrm{m}$ across. Three globular micronuclei about $2 \mu \mathrm{m}$ across, located between two macronuclear nodules (Figs 4G, 5F). Locomotion by swimming forward while rotating about the main cell axis, or by touching the substrate with collar membranelles (Fig. 4C).

Oral apparatus in vivo about $45 \mu \mathrm{m}$ across, but only 30-38 $\mu \mathrm{m}$ across after protargol impregnation; oral cavity extending posteriad to about one-tenth of cell length (Figs 5E, G). About 31-36 collar membranelles formed a slightly spiralled membranellar zone, with a conspicuous gap at the ventral side, and cilia about $25 \mu \mathrm{m}$ long. Bases of the collar membranelles extend obliquely across the peristomial rim, about $10 \mu \mathrm{m}$ long; no elongate bases recognized (Figs 4E, I, 5K). Buccal membranelle not observed, nor the endoral membrane, which may be due to poor staining. 


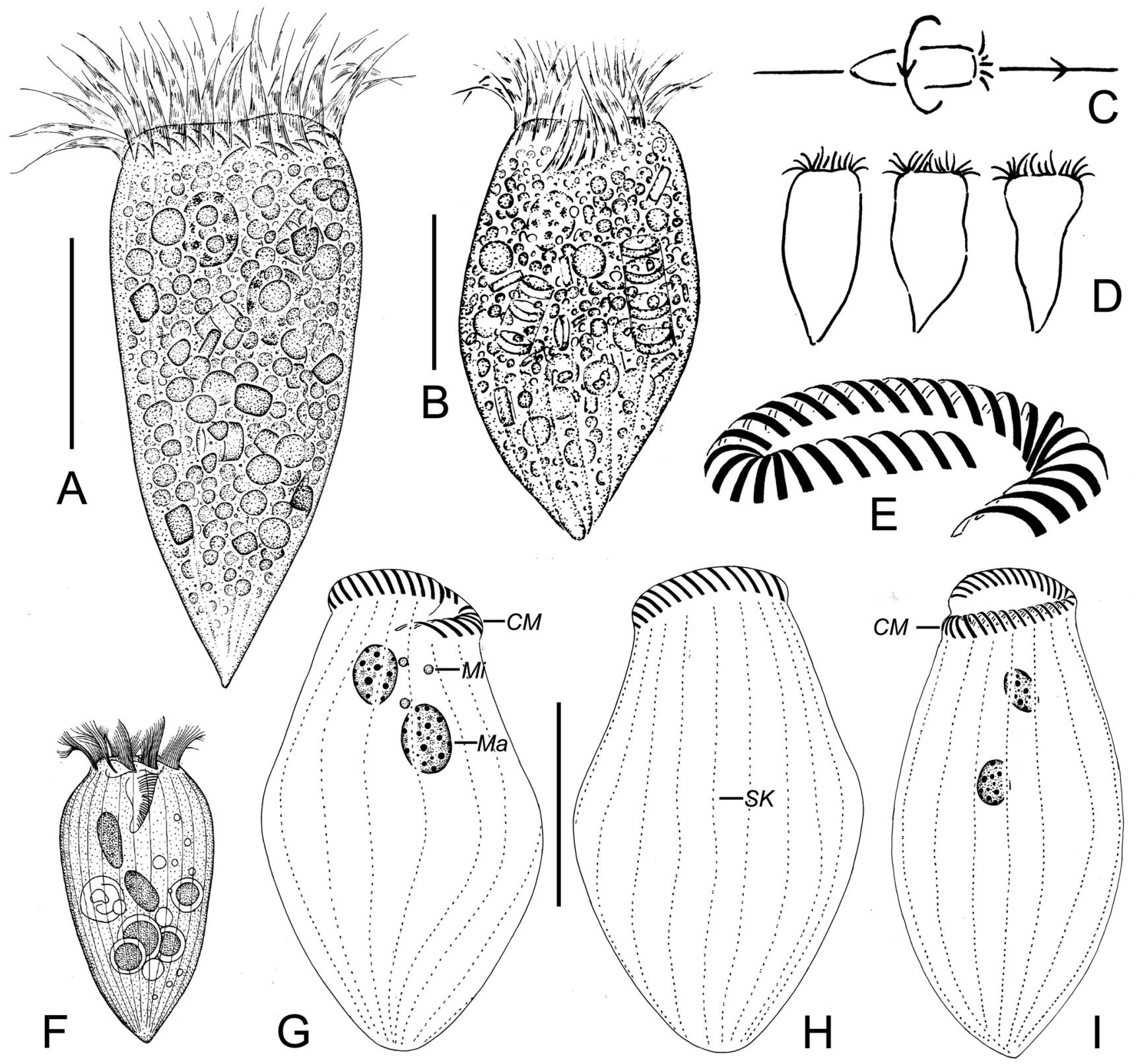

Fig. 4. Parastrombidinopsis pelagica (Fauré-Fremiet, 1924) comb. n. from life (A-D, F) and after protargol staining (E, G-I). (A, B) Ventral views of two individuals. (C) Swimming pattern. (D) Different individuals to show the variations in body shape. (E) Detail of oral membranelles. (F) From Fauré-Fremiet (1924). (G, H) Ventral and dorsal views of the same specimen showing the ciliature. (I) Lateral view of a specimen. CM, collar membranelles; Ma, macronucleus; Mi, micronucleus; SK, somatic kinety. Scale bars: $50 \mu \mathrm{m}$.

Somatic ciliature arranged in 13-15 kineties and evenly distributed around body. The somatic kineties generally commence below membranellar zone and extend to posterior end of cell, without forming a subterminal or subcaudal suture (Figs 4H, 5I, J). Each somatic kinety consists of 52-79 dikinetids; in each dikinetid, both basal bodies bear cilia, with anterior cilium about $4 \mu \mathrm{m}$ long and the posterior cilium about $2 \mu \mathrm{m}$ long (Fig. 5H). One early divider was observed; its oral primordium was located anteriorly at the left of the body (Fig. 5K). 

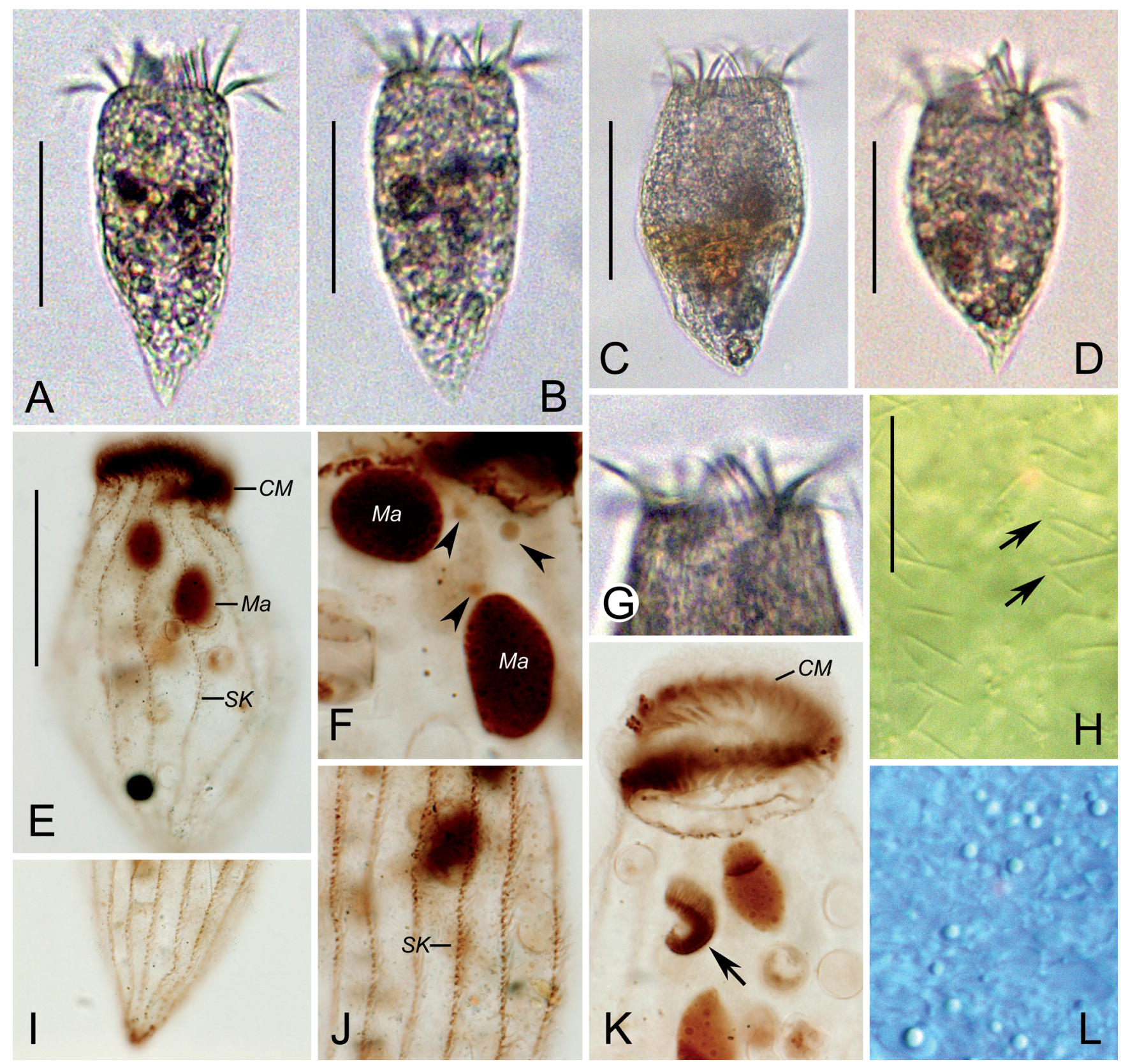

Fig. 5. Photomicrographs of Parastrombidinopsis pelagica (Fauré-Fremiet, 1924) comb. n. from life (A-D, G, H, L) and after protargol staining (E, F, I-K). (A-D) Four individuals, showing the cell shape. (E) Ventral view, showing ciliature. (F) Detail of macronuclei, arrowheads mark micronuclei. (G) Ventral view of oral membranelles. (H) Arrows mark somatic cilia. (I, J) Showing somatic kineties. (K) An early divider; arrow marks oral primordium. (L) Cytoplasm. CM, collar membranelles; Ma, macronucleus; SK, somatic kinety. Scale bars: $20 \mu \mathrm{m}(\mathrm{A}-\mathrm{E}) ; 10 \mu \mathrm{m}(\mathrm{H})$.

Parastrombidinopsis minima Tsai et al., 2008 (Fig. 6, Table 2)

Although the morphology of Parastrombidinopsis minima was well studied by Tsai et al. (2008), some new features have been found in the Haikou population. Thus, a brief description of the new population is sup- plied, along with a phylogenetic analysis based on its SSU rRNA gene sequence.

Locality of the Haikou population: Brackish water in Haikou $\left(20^{\circ} 06^{\prime} \mathrm{N}, 110^{\circ} 33^{\prime} \mathrm{E}\right)$, China, Salinity about $18.2 \%$. 

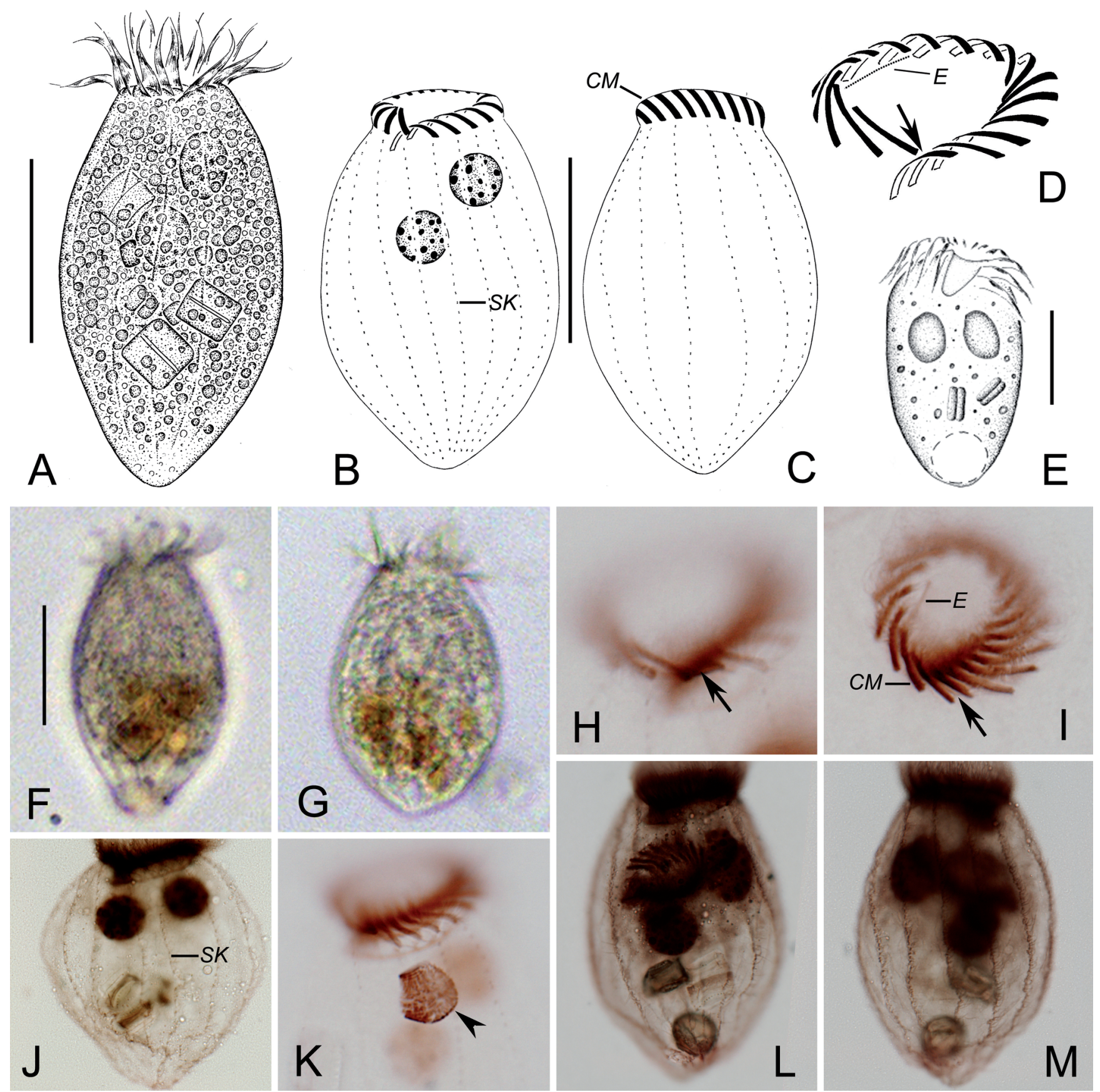

Fig. 6. Drawings and photomicrographs of Parastrombidinopsis minima from life (A, E-G) and after protargol staining (B-D, H-M). $(A, F, G)$ Views of three individuals showing the body shape. (B, C) Ventral and dorsal views of the same specimen showing the ciliature. (D, H, I) Detail of collar membranelles; the arrows mark the ventral gap. (E) From Tsai et al. (2008). (J) Somatic ciliature. (K) An early divider; arrowhead marks the oral primordium. (L, M) Ventral and dorsal views of same specimen showing the ciliature. CM, collar membranelles; E, endoral membrane; SK, somatic kinety. Scale bars: $25 \mu \mathrm{m}$. 
Voucher slide: A protargol slide containing voucher specimens is deposited in the Laboratory of Protozoology, OUC, China (registration number: SW2014042501).

Gene sequence data: The small subunit rRNA gene sequence of Parastrombidinopsis minima Tsai et al., 2008 was deposited in GenBank with accession number MH469226.

Description: Cell size $60-70 \times 30-40 \mu \mathrm{m}$ in vivo, $67-83 \times 55-75 \mu \mathrm{m}$ after protargol staining. Body broadly ellipsoidal with posterior one-third of cell bluntly pointed; length: width ratio about 1.5:1 in vivo. Adoral region narrower than body portion (Figs 6A, F, G).

Cytoplasm colourless, with some lipid droplets about $2 \mu \mathrm{m}$ across and food vacuoles $\sim 8 \mu \mathrm{m}$ across containing some yellow algae (Figs 6F, G). Cell surface smooth, without mineral envelope. Extrusomes and contractile vacuole not observed. Two macronuclear nodules located in the anterior half of cell, 14-21 $\times 12$ $14 \mu \mathrm{m}$ in size after protargol staining, global to ellipsoidal, with several nucleoli $\sim 2-3 \mu \mathrm{m}$ across (Figs 6B, J). Micronucleus not observed. Locomotion by swimming in slow motion, sometimes touching the substrate with collar membranelles.

Oral apparatus in vivo about $20 \mu \mathrm{m}$ across, $24-31 \mu \mathrm{m}$ across after protargol impregnation; oral cavity extending posteriad to about one-tenth of cell length. 16-18 collar membranelles arranged horizontally, with an inconspicuous gap at the ventral side, and cilia about $12 \mu \mathrm{m}$ long. Bases of the collar membranelles extend obliquely across the peristomial rim, each composed of three rows of basal bodies, about $10 \mu \mathrm{m}$ long; the most proximal three to four bases posteriorly prolonged and extending into the oral cavity. Among the elongated membranelles, the most proximal one slightly shorter than others in terms of the length of the base (Figs 6D, H, I). No buccal membranelle observed. Endoral membrane inconspicuous, composed of a single row of basal bodies and lying within the inner wall of buccal cavity (Figs 6D, I).

Somatic ciliature arranged in 14-15 kineties which generally commence below membranellar zone and extend to posterior end of cell, without forming a subterminal or subcaudal suture. Each somatic kinety consisting of 52-79 dikinetids; in each dikinetid, both basal bodies bear a $4 \mu \mathrm{m}$ long cilium (Figs $6 \mathrm{C}, \mathrm{L}, \mathrm{M}$ ).

\section{SSU rRNA gene sequences and phylogenetic analyses}

The SSU rRNA gene sequences of species Parastrombidinopsis costalis sp. n. (Zhuhai) and P. minima studied in this work have been deposited in GenBank. The lengths and GC contents, for Parastrombidinopsis costalis sp. $\mathrm{n}$. and $P$. minima SSU rRNA gene sequences are as follows: Parastrombidinopsis costalis sp. n. (1676 $\mathrm{nt}, \mathrm{GC}=46.72 \%)$; P. minima (1691 nt, $\mathrm{GC}=46.48 \%$ ).

Since the tree topologies from the BI and ML algorithms are similar, only the BI tree is presented, although support values from both methods are indicated at the branch nodes (Fig. 7). In both trees, all Parastrombidinopsis species cluster together, which are the sister to two Strombidinopsis species. In the clade, two sequences of $P$. minima form a group with full support; then cluster with $P$. shimi with support values of 0.99 BI, $80 \%$ ML. Parastrombidinopsis costalis sp. n. also clusters with them with support values $1.00 \mathrm{BI}, 97 \%$ ML. The genus Strombidinopsis is polyphyly by forming two clusters, with one being the basal branch to the subclass Choreotrichia, the other one cluster with Parastrombidinopsis species.

The divergences (base differences per site) between four Parastrombidinopsis SSU rRNA gene sequences (1731 sites) were calculated, ranges from the lowest 0.0035 (two populations of $P$. minima) to the highest 0.0362 (P. costalis and P. shimi).

\section{DISCUSSION}

\section{Parastrombidinopsis costalis sp. n.: comparison be- tween populations and related species (Tables 2, 3)}

The two populations correspond well with each other in terms of cell shape, longitudinal ridge and unevenly spaced somatic kineties, except the Sanya population is smaller than Zhuhai population in cell size $(25-45 \times$ $13-26 \mu \mathrm{m}$ vs $50-73 \times 23-42 \mu \mathrm{m}$ after protargol staining), as well as other size related characters such as number of collar membranelles (16-19 vs 19-21) and number of somatic kineties (6-8 vs 8 ). We think the cell size difference can be considered as populationdependant, and the two populations are conspecific.

The genus Parastrombidinopsis was established by Kim et al. (2005). Prior to the present work, two species have been assigned to the genus: $P$. shimi Kim et al. 2005 and P. minima Tsai et al. 2008. Parastrombidinopsis costalis $\mathrm{sp}$. $\mathrm{n}$. can be separated from the other congeners and all the poorly described choreotrich species by its unique longitudinal ridge on dorsal side.

Besides, the new species differs from the type species Parastrombidinopsis shimi by its: 1) smaller cell size $(30-70 \times 15-40 \mu \mathrm{m}$ vs. $100-170 \times 40-60 \mu \mathrm{m}$ in vivo); 2) fewer collar membranelles (16-21 vs. 36-48); and 3) fewer somatic kineties (6-8 vs. 36-50). 
Table 3. Morphological comparison of Parastrombidinopsis species. All data are based on descriptions of the original and present populations. Measurements in $\mu \mathrm{m}$. CM, collar membranelles; BM, buccal membranelles; SK, somatic kineties.

\begin{tabular}{lllll}
\hline Character & $\begin{array}{l}\text { P. costalis } \\
\text { sp. } \mathrm{n} .\end{array}$ & P. shimi & P. minima & P. pelagica \\
\hline Body size in vivo & $30-70 \times 15-40$ & $112-221 \times 88-176$ & $60-95 \times 30-70$ & $100-170 \times 40-60$ \\
Body size after staining & $25-73 \times 13-42$ & $88-225 \times 55-163$ & $43-83 \times 23-75$ & $95-135 \times 40-66$ \\
Body shape & cylindrical with dorsal ridge & oval & cylindrical & elongated obconical \\
Oral diameter after staining & $8-20$ & $53-98$ & $13-31$ & $30-38$ \\
Number of CM & $16-21$ & $36-48$ & $12-18$ & $31-36$ \\
Number of BM & 1 & 2 & 0 & 0 \\
Number of SK & $6-8$ & $36-50$ & $11-15$ & $13-15$ \\
Number of dikinetids in per somatic & $8-33$ & $68-105$ & $20-39$ & $52-79$ \\
kinety & 2 & $1-4$ & 2 & 2 \\
Number of macronuclei & - & - & - & 3 \\
Number of micronuclei & present work & Kim et al., 2005 & Tsai et al., 2008 and present Fauré-Fremiet, 1924 and \\
Sources & & & work & present work \\
\hline
\end{tabular}

In addition, the new species differs from $P$. minima in the arrangement of the AZM (the proximal end located below the distal end vs. distributed on same horizontal level) and fewer somatic kineties (6-8 vs. 11-15).

Parastrombidinopsis pelagica (Fauré-Fremiet, 1924) comb. n. and comparison with related species (Table 3 )

This species was first reported as Strobilidium pelagicum by Fauré-Fremiet (1924) with a brief description of the organism in vivo. Jankowski (2007) transferred the species to the genus Strombidinopsis Kent, 1881 based only on the original description. The Zhanjiang population corresponds well with the original description regarding the cell size, cell shape, macronucleus, oral membranelles, somatic kineties and habitat, thus, we think our population can be conspecific to Strobilidium pelagicum Fauré-Fremiet, 1924. Given the ventral gap of collar membranelle bases revealed by protargol staining, however, we think this species should be transferred to the genus Parastrombidinopsis Kim et al., 2005 as P. pelagica (Fauré-Fremiet, 1924) comb. n.

Parastrombidinopsis pelagica (Fauré-Fremiet, 1924) comb. n. most resembles $P$. shimi in its cell size and number of collar membranelles, but can be easily separated from the latter by having fewer somatic kineties (13-15 vs. 36-50). Parastrombidinopsis pelagica (Fauré-Fremiet, 1924) comb. n. differs from P. costalis sp. n. by having: 1) a larger cell size $(100-170 \times 40$ $60 \mu \mathrm{m}$ vs. 60-70 $\times 25-40 \mu \mathrm{m}$ in vivo); 2) more collar membranelles (31-36 vs. 19-21); and 3) more somatic kineties (13-15 vs. 6-8). In addition, Parastrombidinopsis pelagica (Fauré-Fremiet, 1924) comb. n. can be separated from $P$. minima by: 1$)$ the arrangement of the AZM (the proximal end located below the distal end vs. distributed on same horizontal level); 2) the larger cell size $(100-170 \times 40-60 \mu \mathrm{m} v s .60-95 \times 30-70 \mu \mathrm{m}$ in vivo); 3 ) and the presence of more collar membranelles (31-36 vs. 12-18).

\section{Parastrombidinopsis minima Tsai et al., 2008 and comparison with related species (Table 3)}

Parastrombidinopsis minima was originally reported by Tsai et al. (2008) based on a Taiwan population. The Haikou population matches the original description in all characteristics, except some population-dependent differences: a slightly larger cell size $(67-83 \times$ 55-75 $\mu \mathrm{m}$ vs. $43-71 \times 23-42 \mu \mathrm{m}$ in the original population after protargol staining), accompanied by higher numbers of collar membranelles (16-18 vs. 12-16) and dikinetids in each somatic kinety (14-15 vs. 11-13). In addition, the large empty vacuole which was described in the posterior cell end of the original population, was not detected in the present population. We thought those differences should be population-dependent, therefore, the Haikou population is in fact conspecific to Parastrombidinopsis minima Tsai et al., 2008.

\section{Phylogenetic analyses}

In both trees, four Parastrombidinopsis sequences group together with high support values suggesting the 


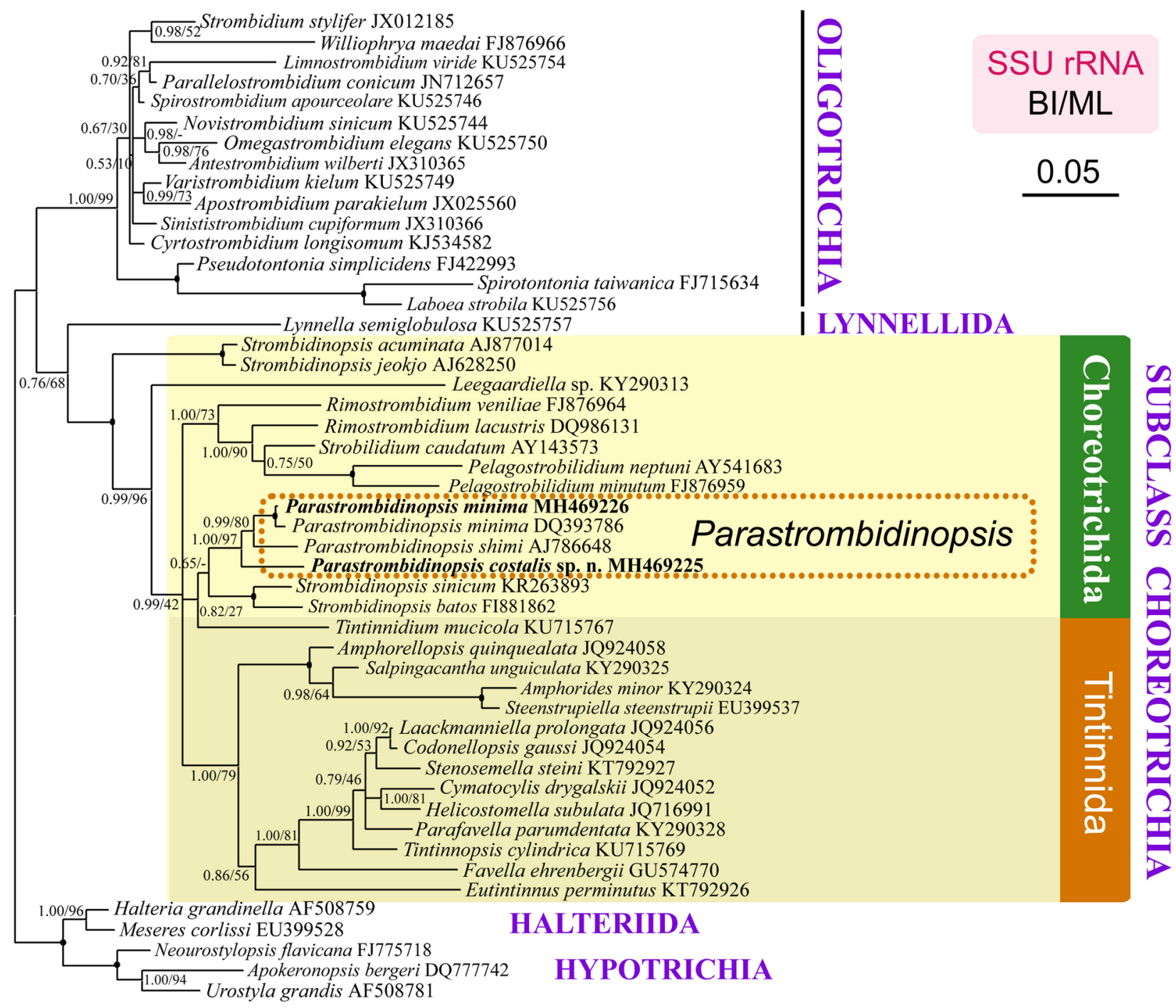

Fig. 7. Bayesian-Inference tree inferred from SSU rRNA gene sequences, indicating the polygenetic positions of species of the genus Parastrombidinopsis. Numbers at the nodes represent support values in the following order: BI posterior probabilities and ML bootstrap values. Disagreements in topology between the BI and ML trees are indicated by a hyphen. Nodes that were well supported (1.00 BI; $100 \% \mathrm{ML})$ are represented by filled circles. Bar $=5$ substitutions per 100 nucleotide positions. Species sequenced in the present study are shown in bold type.

monophyly of the genus as well as the generic affiliation of the new species. The cluster of the two sequences of Parastrombidinopsis minima, as well as their lowest divergence value among the four Parastrombidinopsis sequences, support their conspecific relationship. The genus Strombidinopsis is polyphyly, which is consistent with previous study (Liu et al. 2016). The new species shows highest divergences between the other congeners, valuing 0.0362 with $P$. shimi, 0.0321 and 0.0356 with $P$. minima, which is consistent with its high morphological difference with other congeners.
The ventrally opened AZM, which is commonly displayed in hypotrichs and oligotrichs, has been interpreted as an important plesiomorphic character in the class Spirotrichea, while the closed AZM in choreotrichs is regard as a derived state during evolution (Agatha 2004). Phylogenetic analyses based on molecular data, however, suggest that the Parastrombidinopsis species, who also have a ventral gap in the AZM, nested within the choreotrich clade rather than clustering with either hypotrichs or oligotrichs, as would be expected. Considering the morphological uniformity between Parastrom- 
bidinopsis and other choreotrichs in terms of the distribution of the somatic kineties, as well as in the arrangement of the macronuclear nodules, Parastrombidinopsis surely belongs to the subclass Choreotrichia, as is also suggested by the molecular phylogeny tree. The ventral gap in Parastrombidinopsis, as well as Parastrombidium and Lynnella, probably occurred secondarily during the evolution and represents a synapomorphic retrogression to the plesiomorphic (open) state, as suggested in both Agatha and Strüder-Kypke (2012) and Liu et al. (2015).

Acknowledgements. This work was supported by the National Natural Science Foundation of China (41776133, 31672279, 31702009 , 31801955, 31761133001), Pearl River Science and Technology Nova Program of Guangzhou (201610010162), and Research Group Project No. RGP-083, Deanship of Scientific Research, King Saud University. Many thanks are given to Prof. Weibo Song (OUC) for his constructive suggestions as drafting the paper.

\section{REFERENCES}

Agatha S. (2003) Redescription of Strombidinopsis minima (Gruber, 1884) Lynn et al., 1991 (Protozoa, Ciliophora), with notes on its ontogenesis and distribution. Eur. J. Protistol., 39: 233-244

Agatha S. (2004) A cladistic approach for the classification of oligotrichid ciliates (Ciliophora: Spirotricha). Acta Protozool., 43: 201-217

Agatha S., Riedel-Lorjé J. C. (2006) Redescription of Tintinnopsis cylindrica Daday, 1887 (Ciliophora: Spirotricha) and unification of tintinnid terminology. Acta Protozool., 45: 137-151

Agatha S., Strüder-Kypke M. C. (2007) Phylogeny of the order Choreotrichida (Ciliophora, Spirotricha, Oligotrichea) as inferred from morphology, ultrastructure, ontogenesis, and SSrRNA gene sequences. Eur. J. Protistol., 43: 37-63

Agatha S., Strüder-Kypke M. C. (2012) Reconciling cladistic and genetic analyses in choreotrichid ciliates (ciliophora, spirotricha, oligotrichea). J. Eukaryot. Microbiol., 59: 325-350

Agatha S., Strüder-Kypke M. C., Beran A., Lynn D. H. (2005) Pelagostrobilidium neptuni (Montagnes and Taylor, 1994) and Strombidium biarmatum nov. spec. (Ciliophora, Oligotrichea): phylogenetic position inferred from morphology, ontogenesis, and gene sequence data. Eur. J. Protistol., 41: 65-83

Alekperov I., Buskey E., Snegovaya N. (2007) The free living ciliates of the Mexican Gulf coast near Port Aransascity and its suburbs (South Texas, USA). Protistologica, 5: 101-130

Chen X., Gao S., Liu Y., Wang Y. Y., Wang Y. R., Song W. B. (2016) Enzymatic and chemical mapping of nucleosome distribution in purified micro- and macronuclei of the ciliated model organism, Tetrahymena thermophila. Sci. Chin. Life Sci., 59: 909-919

Chen P. C., Chiang K. P., Tsai, S. F. (2017) Pelagostrobilidium liui n. sp. (Ciliophora, Choreotrichida) from the coastal waters of northeastern Taiwan and an improved description of Pelagostrobilidium minutum Liu et al., 2012. J. Eukaryot. Microbiol., 64: $579-587$

Fauré-Fremiet E. (1924) Contribution à la connaissance des infusoires planktoniques. Bull. Biol. Fr. Belg. Suppl., 6: 1-171

Gao S., Gong J., Lynn D. H., Lin X., Song W. B. (2009) An updated phylogeny of oligotrich and choreotrich ciliates (Protozoa, Cili- ophora, Spirotrichea) with representative taxa collected from Chinese coastal waters. Syst. Biodivers., 7: 235-242

Gao F., Warren A., Zhang Q., Gong J., Miao M., Sun P., Xu D., Huang J., Yi Z., Song W. B. (2016a) The all-data-based evolutionary hypothesis of ciliated protists with a revised classification of the phylum Ciliophora (Eukaryota, Alveolata). Sci. Rep., 6: 24874

Gao F., Huang J., Zhao Y., Li L., Liu W., Miao M., Zhang Q., Li J., Yi Z., El-Serehyi H. A., Warren A., Song W. B. (2017) Systematic studies on ciliates (Alveolata, Ciliophora) in China: progress and achievements based on molecular information. Eur. J. Protistol., 61: 409-423

Gao F., Li J., Song W., Xu D., Warren A., Yi Z., Gao S. (2016b) Multi-gene-based phylogenetic analysis of oligotrich ciliates with emphasis on two dominant groups: cyrtostrombidiids and strombidiids (Protozoa, Ciliophora). Mol. Phylogenet. Evol., 105: $241-250$

Hall T. A. 1999. BioEdit: a user-friendly biological sequence alignment editor and analysis program for Windows 95/98/NT. Nucleic Acids Symp. Ser., 41: 95-98

Huang J., Chen Z., Song W. B., Berger H. (2014) Three-gene based phylogeny of the Urostyloidea (Protista, Ciliophora, Hypotricha), with notes on classification of some core taxa. Mol. Phylogenet. Evol., 70: 337-347

Huang J. B., Luo X., Bourland W. A., Gao F., Gao S. (2016) Multigene-based phylogeny of the ciliate families Amphisiellidae and Trachelostylidae (Protozoa: Ciliophora: Hypotrichia). Mol. Phylogenet. Evol., 101: 101-110

Jankowski A. W. (2007) Phylum Ciliophora Doflein, 1901. In: Alimov, A. F. (Ed.), Protista. Part 2, Handbook on Zoology (pp. 415-993). St. Petersburg: Russian Academy of Sciences, Zoological Institute. (in Russian with English summary).

Kent W. S. (1880-1882). A manual of the Infusoria (Vols. 1-3, 913 pp.). London: David Bogue.

Kim J. S., Jeong H. J., Strüder-Kypke M. C., Lynn D. H., Kim S., Kim J. H., Lee S. H. (2005) Parastrombidinopsis shimi n. gen., n. sp. (Ciliophora: Choreotrichia) from the coastal waters of Korea: morphology and small subunit ribosomal RNA gene sequence. J. Eukaryot. Microbiol., 52: 1-9

Kim Y., Kim S. Y., Lee W., Choi J. K. (2010) New observations on the choreotrich ciliate Strombidinopsis acuminata Fauré-Fremiet, 1924, and comparison with Strombidinopsis jeokjo Jeong et al., 2004. J. Eukaryot. Microbiol., 57: 48-55

Li J., Liu W., Gao S., Warren A., Song W. B. (2013) Multigenebased analyses of the phylogenetic evolution of oligotrich ciliates, with consideration of the internal transcribed spacer 2 secondary structure of three systematically ambiguous genera. Eukaryot. Cell, 12: 430-437

Liu W., Yi Z., Lin X., Warren A., Song W. B. (2012) Phylogeny of three choreotrich genera (Protozoa, Ciliophora, Spirotrichea), with morphological, morphogenetic and molecular investigations on three strobilidiid species. Zool. Scr., 41: 417-434

Liu W., Yi Z., Xu D., Clamp J. C., Li J., Lin X., Song W. B. (2015) Two new genera of planktonic ciliates and insights into the evolution of the family Strombidiidae (Protista, Ciliophora, Oligotrichia). Plos One, 10: e0131726

Liu W., Xu D., Ma H., Al-Farraj S., Warren A., Yi Z. (2016) Taxonomy and molecular systematics of three oligotrich (s.1.) ciliates including descriptions of two new species, Strombidium guangdongense sp. nov. and Strombidinopsis sinicum sp. nov. (Protozoa, Ciliophora). Syst. Biodivers., 14: 452-465

Liu W., Jiang J., Xu Y., Pan X., Qu Z., Luo X., Warren A., Ma H., Pan H. (2017) Great diversity in marine ciliates: fauna studies 
in China seas during the years 2011-2016. Eur. J. Protistol., 61: 424-438

Lynn D. H. 2008. The Ciliated Protozoa: Characterization, Classification, and Guide to the Literature. Dordrecht: Springer.

Lynn D. H., Montagnes D. J. S. (1988) Taxonomic descriptions of some conspicuous species of strobilidiine ciliates (Ciliopora: Choreotrichida) from the Isles of Shoals, Gulf of Maine. J. Mar. Biol. Ass. U.K., 68: 639-658

Medlin L., Elwood H. J., Stickel S., Sogin M. L. (1988) The characterization of enzymatically amplified eukaryotic 16S-like rRNA-coding regions. Gene, 71: 491-499

Miller M., Pfeiffer W., Schwartz T. (2010) Creating the CIPRES Science Gateway for inference of large phylogenetic trees. In: Proceedings of the gateway computing environments workshop $(G C E)$. LA:IEEE, New Orleans. P. 1-8

Montagnes D. J. S., Taylor F. J. R. (1994) The salient features of five marine ciliates in the Class Spirotrichea (Oligotrichia), with notes on their culturing and behaviour. J. Eukaryot. Microbiol., 41: $569-586$

Nylander J. A. A. (2004) MrModeltest. Evolutionary Biology Centre, Uppsala, Uppsala University

Pan X., Bourland W., Song W. B. (2013) Protargol synthesis: An inhouse protocol. J. Eukaryot. Microbiol., 60: 609-614

Petz W., Song W. B., Wilbert N. (1995) Taxonomy and ecology of the ciliate fauna (Protozoa, Ciliophora) in the endopagial and pelagial of the Weddell Sea, Antarctica. Stapfia, 40: 1-223

Ronquist F., Huelsenbeck J. P. (2003) MRBAYES 3: Bayesian phylogenetic inference under mixed models. Bioinformatics, 19: 1572-1574

Santoferrara L. F., Alder V. V., McManus G. B. (2017) Phylogeny, classification and diversity of Choreotrichia and Oligotrichia (Ciliophora, Spirotrichea). Mol. Phylogenet. Evol., 112: 12-22

Santoferrara L. F., McManus G. B. (2017) Integrating dimensions of biodiversity in choreotrichs and oligotrichs of marine plankton. Eur. J. Protistol., 61: 323-330

Small E. B., Lynn D. H. (1985) Phylum ciliophora, doflein, 1901. In: J. J. Lee, S. H. Hutner, \& E. C. Bovee (Eds.), An illustrated guide to the protozoa. (pp. 393-575). Kansas, USA: Society of Protozoologists, Lawrence.

Smith S. A., Song W., Gavrilova N. A., Kurilov A. V., Liu W. W., McManus G. B., Santoferrara L. F. (2018) Dartintinnus alderae n. g., n. sp., a brackish water tintinnid (Ciliophora, Spirotrichea) with dual-ended lorica collapsibility. J. Eukaryot. Microbiol., 65: 400-411

Song W., Wang L., Li L., Al-Farraj S. A., Aleidan A., Smith S., Hu X. Z. (2018) Morphological characterizations of four species of Parallelostrombidium (Ciliophora, Oligotrichia), with a note on the phylogeny of the genus. J. Eukaryot. Microbiol., 65: 679-693

Song W. B. (2005) Taxonomic description of two new marine oligotrichous ciliates (Protozoa, Ciliophora). J. Nat. Hist., 39: 241-252

Song W. B., Bradbury P. C. (1998) Studies on some new and rare reported marine planktonic ciliates (Ciliophora: Oligotrichia) from coastal waters in North China. J. Mar. Biol. Ass. U.K., 78: 767-794

Song W. B., Packroff G. (1997) Taxonomy and morphology of marine ciliates from China with description of two new speceis, Strombidium globosaneum nov. spec. and S. platum nov. spec. (Protozoa, Ciliophora). Arch. Protistenk., 147: 331-360

Song W. B., Warren A., Hu X. (2009) Free-living ciliates in the Bohai and Yellow Seas, China. Science Press, Beijing
Song W. B., Wang M., Warren A. (2000) Redescriptions of three marine ciliates, Strombidium elegans Florentin, 1901, Strombidium sulcatum Claparède \& Lachmann, 1859 and Heterostrombidium paracalkinsi Lei, Xu \& Song, 1999 (Ciliophora, Oligotrichida). Eur. J. Protistol., 36: 327-342

Song W. B., Wilbert N., Warren A. (1999) Three new entocommensal ciliates from digestive tract of sea urchins of the Weddell Sea, Antarctica (Protozoa, Ciliophora). Polar Biol., 22: 232 240

Stamatakis A. (2006) RaxML-VI-HPC: maximum likelihood based phylogenetic analyses with thousands of taxa and mixed models. Bioinformatics, 22: 2688-2690

Stamatakis A., Hoover P., Rougemont J. (2008) A rapid bootstrap algorithm for the RaxML web servers. Syst. Biodivers., 57: 758-771

Tsai S., Xu D., Chung C., Chiang K. (2008) Parastrombidinopsis minima $\mathrm{n}$. sp. (Ciliophora: Oligotrichia) from the coastal waters of northeastern Taiwan: morphology and small subunit ribosomal DNA sequence. J. Eukaryot. Microbiol., 55: 567-573

Wang R., Song W., Yi Z. Z., Lin X. F., Al-Rasheid K. A. S., Hu X. Z. (2018) Morphology and molecular phylogeny of two new species of Spirostrombidium (Ciliophora, Oligotrichia), with a key to species in the genus. Syst. Biodivers. 16: 743-756

Wilbert N. 1975. Eine verbesserte Technik der Protargolimprägnation für Ciliaten. Mikrokosmos, 64: 171-179

Xu D., Song W. B., Warren A. (2006) Morphology and infraciliature of two new species of marine oligotrich ciliates (Ciliophora: Oligotrichida) from China. J. Nat. Hist., 40: 1287-1299

Xu D., Sun P., Song W. B., Warren A. (2008) Studies on a new endocommensal ciliate, Strombidium foissneri nov. sp. (Ciliophora, Oligotrichida), from the intestine of the sea urchin Hemicentrotus pulcherrimus (Camarodonta, Echinoida). Denisia, 23: 273-278

Xu D., Warren A., Song W. B. (2009) Oligotrichs. In: Song, W. B., Warren, A., Hu, X. (ed.), Free-living Ciliates in the Bohai and Yellow Seas, China. Science Press, Beijing, 10: 307-351

Xu D., Jiao N., Ren R., Warren A. (2017) Distribution and diversity of microbial eukaryotes in bathypelagic waters of the South China Sea. J. Eukaryot. Microbiol., 64: 370-382

Yan Y., Fan Y., Chen X. R., Li L. F., Warren A., Al-Farraj S. A., Song W. B. (2016) Taxonomy and phylogeny of three heterotrich ciliates (Protozoa, Ciliophora), with description of a new Blepharisma species. Zool. J. Linn. Soc., 177: 320-334

Zhang Q., Yi Z., Xu D., Al-Rasheid K. A. S., Gong J., Song, W. B. (2010) Molecular phylogeny of oligotrich genera Omegastrombidium and Novistrombidium (Protozoa, Ciliophora) for the systematical relationships within family Strombidiidae. Chin. J. Oceanol. Limnol., 28: 769-777

Zhang Q., Agatha S., Zhang W., Dong J., Yu Y., Jiao N., Gong J. (2017) Three rDNA loci-based phylogenies of tintinnid ciliates (Ciliophora, Spirotrichea, Choreotrichida). J. Eukaryot. Microbiol., 64: 226-241

Zhao X. L., Wang Y. Y., Wang Y. R., Liu Y., Gao S. (2017) Tetrahymena histone methyltransferase TXR1 is required for both H3 and H3.3 lysine 27 methylation. Sci. Chin. Life Sci., 60: 264-270

Received on $2^{\text {nd }}$ July, 2018; revised on $24^{\text {th }}$ October, 2018; accepted on $11^{\text {th }}$ November, 2018 